DOI https://doi.org/10.30525/978-9934-26-045-2-14

\title{
PECULIARITIES OF PROFESSIONAL DEVELOPMENT OF EMPLOYEES OF THE CITY CLINICAL HOSPITAL OF UKRAINE
}

\author{
Bondariev R. V. \\ Doctor of Medicine, \\ Professor at the Department of Surgery \\ with a course of Emergency and Vascular Surgery \\ Bogomolets National Medical University

\section{Ivantsok V. M.} \\ Candidate of Medical Sciences, \\ Assistant of the Department of Surgery \\ with a course of Emergency and Vascular Surgery \\ Bogomolets National Medical University
}

\author{
Bondarieva O. 0. \\ Assistant at the Department of Internal Medicine № 2 \\ Bogomolets National Medical University \\ Kyiv, Ukraine
}

Introduction. In an environment where skills, practical skills and theoretical knowledge are rapidly becoming obsolete, one of the most important factors in providing quality medical care to the population of the City Clinical Hospital (MCL) of Ukraine is the ability to constantly improve the professional level of its employees. In this context, the strategic goals in the direction of improving the efficiency of MCL of Ukraine, the greatest attention is paid to creating conditions aimed at the possibility of professional growth of professionals and their motivation, the formation of a favorable socio-psychological climate [1, p. 56].

Continuous professional development of MCL employees in Ukraine is necessary to improve the quality of medical care. The lack of continuous education of MCL employees will stop their development as specialists, which will naturally affect the quality of medical care. The process of continuous professional training, throughout life, of employees of medical 
institutions is a strategic goal of the development of higher medical education in Ukraine and the world [2, p. 3].

In modern conditions, the role of professional development of MCL employees in Ukraine is to increase efficiency and increase life expectancy, ensure prevention and elimination of diseases, improve physical development, reduce mortality and disability, which is made possible by new knowledge, skills, availability modern medical technologies [3, p.164].

The lack of continuing education of MCL employees naturally affects the quality of medical care, as the lack of continuous education of MCL employees will stop their development as specialists.

In order to develop staff for the acquisition of knowledge and skills, in particular training (which includes more formalized approaches) and independent acquisition of knowledge, different approaches are used.

The problem of professional development of MCL employees in modern theory and practice remains relevant and requires further study and further study and new approaches to improvement.

The aim of the study. Theoretical and methodical substantiation of features of professional development of employees of city clinical hospital of Ukraine.

Presentation of the main research material. Medical reform in Ukraine is aimed at providing medical care for all citizens at the level of developed European countries, to create a patient-oriented health care system. It is planned to improve the quality of medical services, finance the basic package of services, develop and implement a strategy for the development of human resources, the patient chooses the medical institution and the doctor.

The training and continuous development of MCL employees now has a number of features. Thus, the position of the head of MCL can be held by a person who has a higher medical education and higher professional education in management. To replace this position, you need to improve your skills every five years.

Heads of departments are not included in the management, so they do not need to take specialization and advanced training courses in the specialty «Organization and management of health care.»

Doctors are not required to be trained in the pre-certification cycle. During each year it is necessary to gain 50 points of continuous professional development. Points of continuous professional development, doctors can get on cycles of thematic improvement, specialization, courses internship, through participation in exhibitions, scientific and practical conferences, 
symposia, congresses, seminars, workshops, internships in clinics of Ukraine and other countries, simulation trainings, distance learning.

Every five years, doctors are required to be certified or assigned to a previously assigned qualification category. For this purpose, the Attestation Commission, after submitting the necessary documents to the doctors, decides on the assignment or confirmation of the qualification category.

There are also special programs for physicians, statisticians, organizational and methodological departments, managers and deputy managers.

Nursing staff must be certified every 5 years on the basis of a higher education institution approved by the Ministry of Health of Ukraine. Junior medical staff is trained on the basis of a medical institution at the place of work. Medical institutions have developed quality control charts for nursing staff, which contain performance evaluation criteria to determine the quality of medical care.

Results of the research. The most problematic places in the process of mastering the knowledge, skills, practical skills of MCL employees are: inefficient system of staff motivation; the use of outdated and similar programs in the cycles of thematic improvement, specialization, internships, often bureaucratized rules of professional development. In the system of professional education of managerial staff - the acquisition of knowledge, skills, practical skills is also a problem. All this affects the career growth of employees.

Discussion of results. Improving the training of medical staff plays an important role in improving the quality of medical care for the population of Ukraine.

Attendance at congresses, conferences, master classes and other training programs will not give an MCL employee a guaranteed $100 \%$ positive result of the perception of the received information. To do this, the information obtained together it is necessary to implement in practice in a medical institution (MC). This will allow you to remember the information obtained with its practical implementation.

Training of health managers is important. This will ensure rational financial and economic activities in the MCL, as well as the appropriate use of financial, material and labor resources.

A promising form of professional development is distance learning, which will allow MCL employees to learn without leaving the work process.

Also, it is necessary to carry out differentiated preparation and carrying out of courses for training of the medical worker, being guided by his work experience, a position, existence of a qualification category. 
It should also be noted that the most effective result in the professional training of MCL employees will be achieved in combination with self-study.

Conclusions. The most problematic places of the existing management system in the city clinical hospital are: lack of career growth; weak system of motivation of the organization's staff; outdated rules for professional development.

It is recommended to introduce the latest technologies, modern information sources and testing programs in the course of thematic improvement using, for example, taking into account foreign experience in training in the health care system.

Prepare and conduct courses are differentiated depending on the position of the employee, work experience, the availability of a qualification category.

\section{References:}

1. Borshch V., Shchur R., Chuvakov O. Motivation and stimulation mechanism of medical staff indeveloping countries: main challenges and ways of its improving in Ukraine. Baltic Journal of economic studies. 2018. Vol. 4. No 4. P. 56-61.

2. Moroz V.M., Huminskii Yu. Y., Polesia T.L., Fomina L.V. Natsionalnyi dosvid vprovadzhennia yevropeiskykh standartiv vyshchoi medychnoi osvity u Vinnytskomu natsionalnomu medychnomu universyteti im. M.I.Pyrohova. Aktualni problemy suchasnoi vyshchoi medychnoi osvity: natsionalnyi dosvid ta svitovyi vymir: tezy dopovidei navch.-metod. konf., 7 liut. 2019 r. Vinnytsia; Vinnytskyi natsionalnyi medychnyi universytet imeni M.I. Pyrohova, 2019. S. 3-5.

3. Rovenska V.V., Sarzhevska Ye.O. Upravlinnia personalom zakladiv okhorony zdorovia $\mathrm{v}$ novykh umovakh hospodariuvannia ta perspektyvy rozvytku v Ukraini. Ekonomichnyi visnyk Donbasu. 2019. № 3(57). S.162-168. 